\title{
JTRESDA
}

Journal homepage: https://jtresda.ub.ac.id/

\section{Studi Penjadwalan dan Pembiayaan Proyek Trashlog PLTA Orya Genyem Kecamatan Unurum Guay Kabupaten Jayapura Menggunakan Microsoft Project Manager 2016}

\author{
Raya Abdullah $^{1 *}$, Suwanto Marsudi ${ }^{1}$, Evi Nur Cahya ${ }^{1}$ \\ ${ }^{1}$ Jurusan Teknik Pengairan Fakultas Teknik Universitas Brawijaya \\ Jalan MT. Haryono No.167, Malang, 65145, INDONESIA \\ *Koresponensi Email: raya_abdoellah@yahoo.in
}

Abstract: Successful of a project can be seen from how economical and efficient of the project. Minimizing unnecessary expenses to achieve the profits which planned is the goal of this study. The implementation of the Microsoft Project Manager 2016 program aims to assist in scheduling and financing to achieve efficient projects in terms of cost, labor and time. The 3 alternatives used include analysis of heavy equipment productivity, project duration, labor resource requirement, analysis unit cost of work, cost budget plan and s curve. The preparation of this thesis aims to find out the efficiency of the three alternatives reviewed in terms of cost and time project worked. Which results will be different on each alternative. Alternative 1 (90 days with 8 hours/day, total project cost Rp. $7,184,379,188.80$ ), Alternative 2 (90 days with 11 hours/day, total project cost Rp. $7,355,870,347.94$ ) and Alternative 3 (96 days with 8 hours/day, total project cost Rp. 7,019,783,796.95). In terms of cost and time of the three alternatives, can concluded if setting the right number of days and hours of work can be an efficient alternative.

Keywords: Financing, Heavy Equipment, Labor, Microsoft Project Manager 2016, Scheduling

Abstrak: Keberhasilan suatu proyek dapat dilihat dari seberapa ekonomis dan efisien proyek tersebut.Meminimalisir pengeluaran yang tidak diperlukan untuk mencapai keuntungan yang telah direncanakan merupakan tujuan dari studi ini. Penerapan program Microsoft Project Manager 2016 bertujuan guna membantu penjadwalan dan pembiayaan agar tercapai proyek yang efisien dari segi biaya serta waktu. 3 alternatif yang digunakan dalam studi ini membahas tentang analisis produktifitas alat berat, kebutuhan tenaga kerja, durasi proyek, analisis harga satuan pekerjaan, rencana anggaran biaya dan kurva s. Pengerjaan tugas akhir ini bertujuan guna mengetahui efisiensi dari ketiga alternatif yang ditinjau dari segi biaya dan waktu pengerjaan proyek. Yang mana hasilnya akan berbeda pada setiap alternatifnya. Alternatif 1 (90 hari dengan 8 jam/hari, biaya total proyek Rp. 7.184.379.188,80), Alternatif 2 (90 hari dengan 11 jam/hari, biaya total proyek Rp. 7.355.870.347,94) dan Alternatif 3 (96 hari dengan 8 jam/hari, biaya total proyek Rp. 7.019.783.796,95). Ditinjau dari segi biaya dan waktu dari ketiga alternatif, 
dapat disimpulkan bahwa pengaturan jumlah hari dan jam kerja yang tepat dapat menjadi alternatif yang efisien.

Kata Kunci: Alat Berat, Microsoft Project Manager 2016, Penjadwalan, Pembiayaan, Tenaga Kerja,

\section{Pendahuluan}

Dalam kaitan dengan keamanan PLTA, mempertimbangkan material debris yang cukup banyak terbawa aliran Sungai Sermo saat kondisi banjir, maka hal yang perlu dikaji adalah mencegah material debris yang cukup banyak supaya tidak menghalangi Intake pada PLTA.

Kondisi aliran pada Sungai Sermo saat kondisi banjir membawa material debris yang terdiri dari material kayu, ranting pohon dan material sedimen. Yang mana kondisi tersebut dapat sangat mengganggu kinerja dari PLTA. Untuk Itu diperlukan suatu bangunan untuk mengatasi gangguan tersebut. Maka dari itu dibangunlah Trashlog didepan Intake PLTA Genyem.

Dalam suatu proyek tentunya diperlukan pengaturan atau manajemen yang baik untuk kelancarannya. Manajemen proyek merupakan aspek organizing atau pengaturan. Permasalahan organizing atau pengaturan ini sangat diperlukan terutama untuk menangani suatu proyek. Dengan banyaknya pihak yang terlibat dalam proyek konstruksi maka potensi terjadinya konflik sangat besar sehingga dapat dikatakan bahwa proyek konstruksi mengandung konflik yang cukup besar [1]. Maka dari itu, dibutuhkan adanya bentuk organisasi yang sesuai dengan proyek yang akan dikerjakan. Dimana fungsi dari organisasi itu sendiri adalah merubah sesuatu (dapat berupa material, informasi, ataupun masyarakat) melalui suatu tatanan terkoordinasi yang mampu memberikan nilai tambah, sedemikian sehingga organisasi tersebut dapat mencapai tujuannya dengan baik [2].

Proyek adalah kegiatan yang berlangsung dalam durasi atau waktu yang telah direncanakan dalam pengalokasian sumber daya untuk tercapainya tujuan yang sudah ditetapkan. Dalam pelaksanaannya, suatu proyek tidak jarang menghadapi keterbatasan seperti anggaran yang dimiliki, jadwal yang harus dipenuhi dan tersedianya sumber daya. Sehingga untuk tercapainya tujuan dalam suatu proyek memerlukan manajemen yang baik dan benar, meliputi beberapa aspek seperti aspek perencanaan, pengaturan tenaga kerja, pengarahan dan pengendalian. Sukses atau gagalnya dikelolanya suatu proyek konstruksi sangat bergantung pada setiap orang yang mengelolanya. Manajemen dapat disimpulkan sebagai kegiatan mengatur atau memimpin berbagai kegiatan orang atau kelompok orang dalam rangka mencapai tujuan bersama yang ditetapkan [3].

Network planning merupakan sebuah perencanaan (planning) dan pengawasan (kontrol) suatu proyek, dimana merupakan suatu rangkaian kegiatan yang rutin dari serangkaian kegiatan yang dibutuhkan untuk menyelesaikan suatu proyek. Seringkali pada suatu perencanaan ditemukan Lintasan atau Jalur Kritis. Jalur kritis terdiri dari rangkaian kegiatan kritis, dimulai dari kegiatan pertama sampai pada kegiatan terakhir proyek [4] Lintasan kritis (Critical Path) memiliki alur aktivitas-aktivitas yang jumlah waktu pelaksanaannya paling lama. Jadi, lintasan yang paling bias menjadi penentu waktu penyelesaian proyek secara keseluruhan adalah lintasan kritis [5].

Adapun tujuan dari studi ini ialah guna menerapkan Program Microsoft Project Manager 2016 untuk merencanakan jadwal pelaksanaan pekerjaan pada Proyek Trashlog 
PLTA Genyem, sehingga diperoleh durasi atau waktu pekerjaan proyek yang efektif dan efisien.

\section{Bahan dan Metode}

\subsection{Bahan}

PLTA Orya genyem dibangun di Sungai Sermo yang terletak ddi Desa Sentosa, Kecamatan Unurum Guay, Kabupaten Jayapura, Provinsi Papua. Letak geografis PLTA Orya Genyem terletak pada $140^{\circ} 02^{\prime} 04^{\prime \prime}$ BT dan $2^{\circ} 63$ ' 59,68' LS. Secara administrative Pengairan, PLTA Orya Genyem termasuk dalam wilayah kerja Balai Besar Wilayah Sungai Papua, Ditjen SDA, Kementerian PU.

Dalam studi ini diperlukan data sebagai penunjang dalam penyelesaian studi ini, data yang di butuhkan adalah data kontrak proyek yang terdiri dari:

1. Jenis-jenis Pekerjaan yang dilakukan

2. Volume dari setiap bagian Pekerjaan

3. Harga Satuan, Upah dan Bahan Kabupaten Jayapura

4. Waktu yang dibutuhkan dalam penyelesaian proyek

\subsection{Metode}

Metode ialah suatu cara atau proses sistematis yang dipakai guna mencapai tujuan tertentu dengan efisien, yang biasanya dalam bentuk langkah-langkah tetap dan teratur. Adapun langkah - langkah dalam pengerjaan skripsi ini antara lain:

1. Menentukan perhitungan produktifitas alat berat yang dipakai sesuai spesifikasi teknis.

2. Menentukan lamanya durasi (hari) pengerjaan untuk setiap pekerjaan.

3. Analisis kebutuhan sumber daya yang dipakai.

4. Menentukan logika ketergantungan pekerjaan.

5. Penjadwalan proyek (Rescheduling).

6. Leveling sumber daya.

7. Menentukan jadwal pengerjaan proyek dengan menyeluruh yang dapat digambarkan dengan kurva $\mathrm{S}$.

8. Dari hasil yang sudah diperoleh, bisa dilanjutkan untuk tahap pembahasan dari hasil analisa terhadap jumlah sumber daya yang dipakai dan waktu dari ketiga alternative.

9. Selesai.

\subsection{Persamaan}

\subsubsection{Produktifitas Alat Berat Excavator}

Excavator memilki produktifitas yang dapat dicari nilainya menggunakan perhitunyan sebagai berikut ini [6]:

$$
Q=q \times \frac{3600}{C m} \times E
$$

dengan:

$$
\begin{array}{ll}
\mathrm{Q} & =\text { Produktifitas per jam }\left(\mathrm{m}^{3} / \mathrm{jam}: \mathrm{yd}^{3} / \mathrm{jam}\right) \\
\mathrm{q} & =\text { Produksi tiap siklus }\left(\mathrm{m}^{3}, \mathrm{Cu} . \mathrm{Yd}\right) \\
\mathrm{Cm} & =\text { Waktu siklus (detik) } \\
\mathrm{E} & =\text { Efisiensi Kinerja }
\end{array}
$$


1. Produktifitas per siklus

$q=q 1 \times \mathrm{K}$

dengan:

$\mathrm{q}=$ Produktifitas per siklus $\left(\mathrm{m}^{3} ; \mathrm{yd}^{3}\right)$

$\mathrm{q} 1$ = Kapasitas bucket yang sudah ada/terdapat pada spesifikasi alatnya

$\mathrm{K}=$ Faktor Bucket

Tabel 1. Bucket Faktor [6]

\begin{tabular}{ccc}
\hline Kondisi Operasi & Kondisi Lapangan & Faktor Bucket $(\mathrm{Fb})$ \\
\hline Mudah & Lempung, Tanah Lembut, Tanah Biasa & $1,1-1,2$ \\
Sedang & Kering, Tanah Biasa Berpasir & $1,0-1,1$ \\
Agak Sulit & Tanah Biasa Berbatu & $1,0-0,9$ \\
Sulit & Batu Pecah Hasil & $0,9-0,8$ \\
\hline
\end{tabular}

Bucket Faktor adalah tingkat kekerasan tanah yang mana bergantung dari jenis tanahnya.

2. Waktu Siklus

$\mathrm{Cm}=$ Lama menggali + Lama berputar $($ Load $)+$ Lama membuang +

Lama berputar (empty)

Pers. 2

Tabel 2. Lama Menggali Excavator (Detik) [6]

\begin{tabular}{ccccc}
\hline Kedalaman gali & Ringan & Rata-rata & $\begin{array}{c}\text { Agak } \\
\text { susah }\end{array}$ & Susah \\
\hline $0 \mathrm{~m}-2 \mathrm{~m}$ & 6 & 9 & 15 & 26 \\
$2 \mathrm{~m}-4 \mathrm{~m}$ & 7 & 11 & 17 & 28 \\
$>4 \mathrm{~m}$ & 8 & 13 & 19 & 30 \\
\hline
\end{tabular}

Lama menggali excavator ialah waktu yang dibutuhkan excavator dalam melakukan sekali penggalian per meter.

Lama membuang berdasarkan kondisi pada tempat pembuangan material

$$
\begin{array}{lll}
\text { Satuan (detik): } & \text { Buang ke dalam Dump Truck } & =5-8 \text { detik } \\
& \text { Buang ke tempat pembuangan } & =3-6 \text { detik }
\end{array}
$$

Tabel 3. Lama berputar Excavator (detik) [7]

\begin{tabular}{cc}
\hline Sudut Putar & Waktu Putar \\
\hline $45^{\circ}-90^{\circ}$ & $4-7$ \\
$90^{\circ}-180^{\circ}$ & $5-8$ \\
\hline
\end{tabular}

Lama berputar Excavator adalah waktu yang dibutuhkan excavator untuk sekali berputar tergantung dari sudut dan kecepatan putarnya. 
3. Efisiensi Kerja

Tabel 4. Efisiensi Kerja Excavator [8]

\begin{tabular}{cc}
\hline Kondisi Operasi & Efisiensi Kerja \\
\hline Baik & 0,83 \\
Rata-rata & 0,75 \\
Agak susah & 0,67 \\
Susah & 0,58 \\
\hline
\end{tabular}

Efisiensi kerja excavator ialah nilai yang ditentukan dari gabungan beberapa faktor untuk mempermudahnya.

\subsubsection{Produktifitas Alat Berat Dump Truck}

Produktifitas Dump Truck dapat dihitung menggunakan rumus [9]:

$$
P=C \times \frac{60}{C m t} \times E t
$$

dengan:

$\mathrm{P}=$ Produktifitas per jam $\left(\mathrm{m}^{3} / \mathrm{jam} ; \mathrm{yd}^{3} / \mathrm{jam}\right)$

$\mathrm{Cmt} \quad=$ Lama Siklus pada dump truck

Et $\quad=$ Efisiensi kinerja

$\mathrm{C}=$ Produktifitas tiap siklusnya

1. Produktifitas Tiap Siklus

$C=n \times q 1 \times \mathrm{K}$

dengan:

$\mathrm{n}=$ Jumlah rit pengisian

$\mathrm{q} 1=$ Bucket Capacity loader $\left(\mathrm{m}^{3} ; \mathrm{yd}^{3}\right)$

$\mathrm{K}=$ Bucket Factor loader

2. Lama Siklus pada Dump Truck (Cmt)

$C m t=n \times C m s+\frac{D}{V_{1}}+t_{1}+\frac{D}{V_{2}}+t_{2}$

Pers. 4

dengan:

$\mathrm{Cmt}=$ Lama siklus pada Dump Truck (detik)

$\mathrm{n} \quad=$ Jumlah volume pengisian

$\mathrm{D} \quad=$ Jarak tempuh dump truck

$\mathrm{V}_{1} \quad=$ Kecepatan rerata truck pada saat isi/bermuatan $(\mathrm{m} / \mathrm{menit})$

$\mathrm{V}_{2} \quad=$ Kecepatan rerata truck pada saat kosong $(\mathrm{m} / \mathrm{menit})$

$\mathrm{t}_{1} \quad=$ Lama dumping

$\mathrm{t}_{2}=$ Lama memposisikan truck dan loader siap mengisi

Cms = Lama siklus loader 
Tabel 5. Lamanya Waktu Dumping ( $\left.t_{1}\right)[8]$

\begin{tabular}{cc}
\hline Kondisi Operasi & $\mathrm{t}_{1}$, menit \\
\hline Baik & $0,5-0,7$ \\
Rata-rata & $1,0-1,3$ \\
Tidak baik & $1,5-2,0$ \\
\hline
\end{tabular}

Lamanya waktu dumping ialah waktu yang dibutuhkan untuk menuangkan materian yang berada di bak dump truck.

Tabel 6. Lamanya Memposisikan Truck dan Loader Siap Mengisi ( $\left.t_{2}\right)[8]$

\begin{tabular}{cc}
\hline Kondisi Operasi & $\mathrm{t}_{2}$, menit \\
\hline Baik & $0,5-0,7$ \\
Rata-rata & $0,25-0,35$ \\
Tidak Baik & $0,4-0,5$ \\
\hline
\end{tabular}

Lamanya memposisikan truck dan loader siap mengisi ialah waktu yang diperlukan guna memposisikan truck dan loader.

3. Menentukan Efisiensi Kinerja

Efisiensi kerja dump truck ialah nilai yang ditentukan dari gabungan beberapa faktor untuk mempermudahnya. Untuk menentukan efisiensi kinerja dapat menggunakan nilai yang sudah ada pada tabel berikut:

Tabel 7. Efisiensi Kinerja Dump Truck [8]

\begin{tabular}{cc}
\hline Kondisi Opersai & Efisiensi Kinerja \\
\hline Baik & 0,83 \\
Rata-rata & 0,80 \\
Agak Susah & 0,75 \\
Susah & 0,70 \\
\hline
\end{tabular}

\subsubsection{Produktifitas Alat Berat Concrete Mixer}

Concrete Mixer mempunyai produktifitas yang dapat dicari nilainya menggunakan persamaan berikut [10]:

$$
Q=\frac{V \times F a \times 60}{1000 \times T s} m^{3}
$$

Pers. 5

dengan:

$$
\begin{array}{ll}
\mathrm{Q} & =\text { Produktifitas/Kapasitas produksi }\left(\mathrm{m}^{3} / \mathrm{jam}\right) \\
\mathrm{V} \text { atau } \mathrm{Cp} & =\text { Volume/Kapasitas mencampur }\left(\text { diambil } 0,5 \mathrm{~m}^{3}\right) \\
\mathrm{Fa} & =\text { Faktor efisiensi alat } \\
\mathrm{Ts} & =\text { Lama siklus } \\
\mathrm{T} 1 & =\text { Lama mengisi (dipakai } 4 \text { menit) } \\
\mathrm{T} 2 & =\text { Lama mencampur (dipakai } 3 \text { menit) } \\
\mathrm{T} 3 & =\text { Lama menuang (dipakai } 1 \text { menit) } \\
\mathrm{T} 4 & =\text { Lama menunggu (dipakai } 1 \text { menit) }
\end{array}
$$




\section{Hasil dan Pembahasan}

\subsection{Analisis Harga Satuan Pekerjaan}

Harga satuan pekerjaan adalah bagian yang sangat penting guna menentukan besar dan kecilnya biaya yang akan dikeluarkan. Guna mendapat hasil analisis harga satuan Pekerjaan digunakanlah perkalian antara koefisien pekerjaan dengan upah (gaji) dari tiap bagian pekerjaan, untuk koefisien pekerjaan dan upah (gaji) pekerjaan didapatkan dari Harga Satuan Pekerjaan dari Kementerian PUPR.

\subsection{Analisa Perubahan Alat Berat}

Dari rencana kerja proyek terdapat perbedaan jumlah alat berat pada 3 alternatif, perbedaan jumlah alat berat terdapat pada beberapa pekerjaan yang membutuhkan saja, dan tentu saja itu akan berpengaruh kepada perhitungan serta mengubah jumlah durasi dan tentu saja juga merubah harga untuk menyewa alat berat.

Tabel 8. Perbandingan Jumlah Alat Berat 3 Alternatif

\begin{tabular}{cccc}
\hline Nama Alat Berat & Alternatif 1 & Alternatif 2 & Alternatif 3 \\
\hline Waktu Pelaksanaan & $\begin{array}{c}90 \text { hari } \\
(8 \text { jam/hari })\end{array}$ & $\begin{array}{c}90 \text { hari } \\
(11 \text { jam/hari })\end{array}$ & $\begin{array}{c}96 \text { hari } \\
(8 \text { jam/hari })\end{array}$ \\
\hline Flat Bed Truck & 9 & 7 & 7 \\
Excavator & 1 & 1 & 1 \\
Dump Truck & 1 & 1 & 1 \\
Pompa Air Diesel 20 KW & 5 & 4 & 5 \\
Bore Pile & 3 & 2 & 3 \\
Concrete Pump & 2 & 2 & 2 \\
Pompa dan Conveyor Beton & 2 & 2 & 2 \\
Concrete Mixer & 2 & 2 & 2 \\
\hline
\end{tabular}

\subsection{Analisis Jumlah Tenaga Kerja}

Dari perbedaan durasi pada ketiga alternatif terdapat perbedaan jumlah tenaga kerja pada pelaksanaan proyek. Dari penyusunan alternatif 2 dan alternatif 3 diperoleh jumlah total tenaga kerja pelaksana yang lebih sedikit dibandingkan dengan jumlah total tenaga kerja pelaksana pada alternatif 1 .

Tabel 9. Perbandingan Jumlah Tenaga Kerja

\begin{tabular}{cccc}
\hline Uraian & Alternatif 1 & Alternatif 2 & Alternatif 3 \\
\hline Waktu Pelaksanaan & 90 Hari (8 jam) & 90 hari (11 jam) & 96 hari (8 jam) \\
Tenaga Kerja & 108 & 95 & 107 \\
\hline
\end{tabular}

\subsection{Analisa Perbedaan Biaya dan Waktu}

Dalam pembahasan studi ini menggunakan 3 alternatif analisis percepatan dengan perkiraan biaya normal proyek sebesar Rp. 7.472.305.164,33. Untuk hasil analisa dari ketiga alternatif adalah seperti berikut ini: 
Tabel 10. Rekapitulasi Biaya dan Waktu

\begin{tabular}{cccc}
\hline Uraian & Alternatif 1 & Alternatif 2 & Alternatif 3 \\
\hline Waktu & 90 hari (8 jam/hari) & 90 hari (11 jam/hari) & 96 hari (8 jam/hari) \\
Biaya & Rp. 7.184.379.188,80 & Rp. 7.355.870.347,94 & Rp. \\
& & & $7.019 .783 .796,00$ \\
\hline
\end{tabular}

\section{Kesimpulan}

Dari hasil analisis dengan memakai Program Microsoft Project Manager 2016 serta perhitungan manual kepada pekerjaan Proyek Pembuatan Trashlog PLTA Orya Genyem didapatkan hasil kesimpulan seperti berikut:

1. Menurut data konrak pada Proyek Pembuatan Trashlog PLTA Orya dengan jumlah biaya Rp. 7.472.305.164,33 . Menunjukkan bahwa ada pengurangan jumlah hari kerja dari 3 alternatif yang digunakan yang mana data kontrak proyek yang digunakan sebagai acuan. Ketiga alternatif yang telah dibuat menunjukkan adanya perbedaan durasi yang mana pada alternatif 1 (90 hari dengan 8 jam/hari), alternatif 2 (90 hari dengan 11 jam/hari).sedangkan alternatif 3 (96 hari dengan 8 jam/hari).

2. Dari hasil analisis penjadwalan dan pembiayaan pekerjaan yang dilakukan telah dilakukan pada Proyek Proyek Pembuatan Trashlog PLTA Orya diketahui, semakin dipercepat durasi proyek, maka jumlah biaya semakin meningkat. Dan untuk menentukan alternatif manakah yang lebih efektif serta efisien, maka perlu mengetahui seberapa pentingkah bangunan yang akan dibangun. Jika dilihat dari segi efisiensi maka alternatif 3 adalah yang paling efisien

\section{Daftar Pustaka}

[1] W. I. Ervianto, Manajemen Proyek Konstruksi. Yogyakarta: Andi, 2002.

[2] I. Dipohusodo, Manajemen Konstruksi Jilid I. Yogyakarta: Kanisius, 1996.

[3] Nugraha, Paulus and Friends, Manajemen Proyek Konstruksi 2. Surabaya: Kartika Yudha, 1986.

[4] I. Soeharto, Manajemen Proyek (Dari Konseptual sampai Operasional) Jilid 1. Jakarta: Erlangga, 1999.

[5] S. Badri, Dasar-dasar Network Planning (Dasar-dasar Pelaksanaan Kerja). Jakarta: Rineka Cipta, 1997.

[6] Rochmanhadi, Perhitungan Biaya Pelaksanaan Pekerjaan dengan Menggunakan Alat-alat Berat. Jakarta: Badan Penerbit Pekerjaan Umum, 1985.

[7] Rochmanhadi, Alat-alat Berat dan Penggunaannya, Cetakan III. Jakarta: Yayasan Badan Penerbit Pekerjaan Umum, 1989.

[8] D. Lydianingtias and Suhariyanto, Alat Berat. Malang: Polinema Press, 2018.

[9] S. F. Rostiyanti Alat Berat Untuk Proyek Konstruksi. Jakarta: Rineka Cipta, 2008.

[10] Menteri Pekerjaan Umum dan Perumahan Rakyat, Peraturan Menteri Pekerjaan Umum dan Perumahan Rakyat Nomor 28/PRT/M/2016 Tahun 2016 tentang Pedoman Analisis Harga Satuan Pekerjaan Bidang Pekerjaan Umum. Jakarta: JDIH Kementerian PUPR, 2016. 